\title{
Cytokines activate genes of the endocytotic pathway in insulin-producing RINm5F cells
}

\author{
K. L. A. Souza ${ }^{1,2}$ • M. Elsner ${ }^{1}$ P. C. F. Mathias $^{2} \cdot$ S. Lenzen ${ }^{1} \cdot$ M. Tiedge ${ }^{1}$ \\ ${ }^{1}$ Institute of Clinical Biochemistry, Hanover Medical School, Hanover, Germany \\ ${ }^{2}$ Department of Cell Biology and Genetics, University of Maringá, Maringá, Brazil
}

\begin{abstract}
Aims/hypothesis. Cytokines are important humoral mediators of beta cell destruction in autoimmune diabetes. The aim of this study was to identify novel cytokine-induced genes in insulin-producing RINm5F cells, which may contribute to beta cell death or survival.

Methods. A global gene expression profile in cytokine-exposed insulin-producing RINm5F cells was achieved by automated restriction fragment differential display PCR. The expression of selected candidate genes was confirmed by real-time RT-PCR analysis. Results. Exposure of RINm5F cells to IL-1 $\beta$ or to a cytokine mixture (IL-1 $\beta$, TNF- $\alpha$, IFN- $\gamma$ ) for $6 \mathrm{~h}$ resulted in the differential expression of a functional gene cluster. Apart from the well-known up-regulation of the cytokine-responsive genes iNOS, $N F-\kappa B$, $M n S O D$ and $H s p 70$, several genes that belong to the functional cluster of the endocytotic pathway were identified. These endocytotic genes comprised: clathrin, megalin, synaptotagmin and calcineurin, which were up-regulated by IL- $1 \beta$ or the cytokine mixture.
\end{abstract}

In contrast, the expression of the calcineurin inhibitor CAIN and of the GDP/GTP exchange protein Rab3 was down-regulated by cytokines. Other up-regulated cytokine-responsive genes were: agrin, murine adherent macrophage protein mRNA $(M A M A)$ and transport-associated protein $(T A P 1 / M T P)$, whereas the plasma membrane calcium ATPase (PMCA) 2 and $P M C A 3$ genes were down-regulated by cytokines.

Conclusions/interpretation. Our results indicate that genes of the endocytotic pathway are regulated by pro-inflammatory cytokines. This might affect the density of cytokine receptors at the beta cell surface and concomitantly the sensitivity of the cells to cytokine toxicity. A better understanding of the functional cross-talk between endocytotic and cytokine signalling pathways could further the development of novel strategies to protect pancreatic beta cells against toxic effects of pro-inflammatory cytokines.

Keywords Cytokines $\cdot$ Diabetes $\cdot$ Differential display · Gene expression · IFN- $\gamma \cdot$ IL- $1 \beta$. Insulin-producing RINm5F cells $\cdot$ TNF- $\alpha$
Received: 9 March 2004 / Accepted: 6 May 2004

Published online: 10 July 2004

(C) Springer-Verlag 2004

M. Tiedge (๘)

Institute of Clinical Biochemistry, Hanover Medical School, 30623 Hanover, Germany

E-mail: tiedge.markus@mh-hannover.de

Tel.: +49-511-5326329, Fax: +49-511-5323584

Electronic Supplementary Material

Electronic supplementary material is available in the online version of this article at http://dx.doi.org/10.1007/s00125-0041435-2

\section{Introduction}

Pro-inflammatory cytokines such as IL- $1 \beta$, TNF- $\alpha$ and IFN- $\gamma$ play an important role in the pathogenesis of Type 1 diabetes mellitus [1, 2, 3, 4]. These humoral

Abbreviations: CAIN, calcineurin inhibitor .

EP, extension-protected adaptor $\cdot$ Hsp70, heat shock protein 70 . iNOS, inducible nitric oxide synthase - MAMA, murine adherent macrophage protein $\cdot \mathrm{MnSOD}$, manganese superoxide dismutase $\cdot \mathrm{NF}-\kappa \mathrm{B}$, nuclear factor kappa $\mathrm{B} \cdot \mathrm{NO}$, nitric oxide PMCA, plasma membrane calcium ATPase $\cdot$ Rab3, rab3 GDP/GTP exchange protein - RFDD-PCR, restriction fragment differential display PCR · SD, standard adaptor · Syt, synaptotagmin V . TAP1, transport-associated protein 1 
mediators of autoimmunity are released by macrophages and $\mathrm{T}$ cells in infiltrated islets of Langerhans and synergistically initiate complex signal pathways in pancreatic beta cells, which cause impaired function and ultimately cell death by apoptosis or necrosis. Although species, in particular rodents and humans, differ in their sensitivity towards cytokines, it is generally accepted that cytokine toxicity is a universal principle of autoimmune destruction of pancreatic beta cells $[4,5]$. The signal pathways of pro-inflammatory cytokines involve binding to specific receptors, activation of mitogen- and stress-activated protein kinases and mobilisation of transcription factors such as NF- $\kappa \mathrm{B}$, STAT-1 and c-myc, which mediate upor down-regulation of gene expression and beta cell apoptosis [4]. In particular the generation of nitric oxide (NO) by induction of inducible nitric oxide synthase (iNOS) and of oxygen free radicals by unknown mechanisms are thought to participate in the signal pathways of programmed cell death and the direct oxidative attack of beta cell structures $[3,6,7]$.

Recent studies using the microarray technology indicate that the deleterious effects of cytokines upon insulin-producing cells result from a re-programming of the gene expression profile that is responsible for cell death and cell survival $[8,9,10,11,12]$. Overall several hundred genes were affected by cytokines in insulin-producing cell lines and primary beta cells. Among these genes there are functional classes such as metabolism, transcription factors and apoptosis. The aim of these global gene expression analyses approaches is the identification of functional gene clusters, which may open new perspectives for interventional strategies against beta cell destruction. Since there are presently no specific arrays covering all expressed beta cell genes, the available information on global cytokine-modified genes in beta cells is, by definition, incomplete.

In this study we did gene expression screening by automated restriction fragment differential display PCR (RFDD-PCR) [13] to identify functionally relevant gene clusters in insulin-producing RINm5F cells exposed either to IL-1 $\beta$ alone or to a combination of cytokines. Using this approach, we identified a cluster of cytokine-regulated genes coding for structures participating in the endocytotic pathway. Endocytosis of cytokine receptors has been described in different cell types as a protective mechanism by which cells down-regulate the signal transduction and the consequent deleterious effects of cytokines $[14,15]$. Notably, IL- $1 \beta$ is able to increase and decrease the rate of endocytosis, an effect that may be linked to NO production by iNOS [16]. The endocytotic machinery is composed of various proteins, which may participate directly or indirectly in the signal pathways of cytokine-mediated beta cell destruction $[17,18,19]$. On the basis of these results, we propose a novel regulatory principle that might operate in insulin-producing cells exposed to pro-inflammatory cytokines.

\section{Materials and methods}

Chemicals. Cytokines and the dNTP mixture were obtained from PromoCell (Heidelberg, Germany), Escherichia coli DNA polymerase I and DNA ligase, and the TaqI restriction endonuclease from New England Biolabs (Frankfurt, Germany), ribonuclease $\mathrm{H}$ from MBI Fermentas (St. Leon-Rot, Germany), and Biotherm Taq polymerase from GeneCraft (Münster, Germany). The sizing standard was from Li-cor (Lincoln, Neb., USA) and the GelStar nucleic acid gel stain from BMA (Rockland, Me., USA). The SuperScript II RT reverse transcriptase, T4 DNA ligase and all tissue culture equipment were purchased from Invitrogen (Karlsruhe, Germany). All primers and adaptors were from MWG-Biotech (Ebersberg, Germany). All other reagents were from Sigma Chemicals (Munich, Germany).

Cell culture and cytokine incubation. Insulin-producing RINm5F cells were cultured as described $[6,20]$ in RPMI 1640 medium, supplemented with $10 \mathrm{mmol} / \mathrm{l}$ glucose, $10 \%$ (v/v) fetal calf serum, penicillin and streptomycin in a humidified atmosphere at $37^{\circ} \mathrm{C}$ and $5 \% \mathrm{CO}_{2}$. Cells were seeded at a density of $2 \times 10^{6}$ per $90-\mathrm{mm}$ plastic dish and grown to confluence within 2 days. Thereafter cells were exposed for $6 \mathrm{~h}$, either to IL-1 $\beta$ at $60 \mathrm{U} / \mathrm{ml}(0.6 \mathrm{ng} / \mathrm{ml})$ or $600 \mathrm{U} / \mathrm{ml}(6 \mathrm{ng} / \mathrm{ml})$, or to a cytokine


TNF- $\alpha(9.3 \mathrm{ng} / \mathrm{ml})$ and $14 \mathrm{U} / \mathrm{ml}$ IFN- $\gamma(1.4 \mathrm{ng} / \mathrm{ml})$. In all experiments the cytokine stimulation increased the production of $\mathrm{NO}$, which was measured through accumulation of $\mathrm{NO}^{2-}$ and $\mathrm{NO}^{3-}$ in the medium [21] (data not shown). Control RINm5F cells were grown in the absence of cytokines.

$m R N A$ isolation. Total RNA was isolated using the guanidine thiocyanate method [22]. The quality of the total RNA was verified by comparing the intensities of the 28S and 18S rRNA bands in agarose gel electrophoresis. The mRNA was isolated by the use of magnetic beads coupled with oligo-dT according to the manufacturer's manual (microMACS mRNA isolation Kit, Miltenyi Biotec, Bergisch Gladbach, Germany) and quantified by fluorimetric assay (RiboGreen RNA Quantitation Kit, Molecular Probes Europe, Leiden, The Netherlands).

Restriction fragment differential display PCR analysis. The general procedure followed the guidelines of the Restriction Fragment Differential Display system (DisplayPROFILE Kit, Qbiogene, Heidelberg, Germany). First, 500 ng of mRNA were reverse transcribed into complementary DNA using an oligo$\mathrm{dT}_{18} \mathrm{NV}$ primer followed by second strand synthesis. The obtained double-strand cDNA was purified through columns of silica-gel (QIAquick PCR Purification Kit, Qiagen, Hilden, Germany) and was then cut by the TaqI restriction enzyme to obtain smaller fragments with cohesive ends. Using T4 DNA ligase, a standard adaptor (SD) and an extension-protected adaptor (EP) were ligated to the cohesive ends of the TaqI cDNA fragments. The use of the two adaptors allows the generation of the final RFDD template for PCR amplification using a fluorescently labelled standard extension primer and a specific $3^{\prime}$-extension primer. The sequences of the EP adaptor were 5'-ACTGGTCTCGTAGACTGCGTACC-3' (upper strand)


$5^{\prime}$ end was modified with a phosphate group while the last nucleotide at the $3^{\prime}$ end was ligated to an amino extension protection group on carbon 7. The sequences of the SD adaptor were 5'-GCGATGAGTCCTGAC-3' (upper strand) and 5'-CGGTCAGGACTCAT-3' (lower strand) [23]. Ligation of adaptors to cDNA restriction fragments has four possible outcomes: (EP-SD, SD-EP, EP-EP, and SD-SD). Notably, only the EP-SD and SD-EP cDNA fragments can be visualised in the 
Table 1. Sequences of the primers used for real-time RT-PCR gene expression quantification

\begin{tabular}{|c|c|c|}
\hline Gene & & Primer sequence \\
\hline \multirow[t]{2}{*}{ Agrin } & $\mathrm{Fw}$ & 5'-AGAAGAATGCTTGCCCTGCTACG-3' \\
\hline & $\mathrm{Rv}$ & 5'-ATGCGCCGTTGCTGGTTG-3' \\
\hline \multirow[t]{2}{*}{$\beta$-actin } & Fw & 5'-GCATGTGCAAGGCCGGCT-3' \\
\hline & $\mathrm{Rv}$ & 5'-CACCATCACACCCTGGTGCCTA-3' \\
\hline \multirow{2}{*}{ CAIN } & Fw & 5'-AATGCCAGCTCCACAATTGAAGA-3' \\
\hline & $\mathrm{Rv}$ & 5'-CTTCTGCTTCCTGAGCCTCCTTT-3' \\
\hline \multirow[t]{2}{*}{ Calcineurin } & Fw & 5'-AACTTGCTGGATATTGATGCCCC-3' \\
\hline & $\mathrm{Rv}$ & 5'-GCAGGAGATCCTCCCACTTCAAA-3' \\
\hline \multirow[t]{2}{*}{ Clathrin } & Fw & 5'-CTCAGCCAGTGAAGATGTTTGATCG-3' \\
\hline & $\mathrm{Rv}$ & 5'-GCAGATATGCCAGTCAGGAGCAAC-3' \\
\hline \multirow[t]{2}{*}{ Hsp70 } & Fw & 5'-GCTCATCAAGCGCAACTCCAC-3' \\
\hline & $\mathrm{Rv}$ & 5'-TCGTACACCTGGATCAGCACCC-3' \\
\hline \multirow[t]{2}{*}{ iNOS } & Fw & 5'-TCGTACTTGGGATGCTCCATGG-3' \\
\hline & $\mathrm{Rv}$ & 5'-TCCTGCAGGCTCACGGTCAA-3' \\
\hline \multirow[t]{2}{*}{ MAMA } & Fw & 5'-TCATGCTGGATGAGGTGGAATG-3' \\
\hline & $\mathrm{Rv}$ & 5'-TCCTTCTCATGCCCGCAGTG-3' \\
\hline \multirow[t]{2}{*}{ Rab3 } & Fw & 5'-TCGGAAGGTGTACAAGGGAATGCT-3' \\
\hline & $\mathrm{Rv}$ & 5'-AGTAATGGGTCTGGGCAATCTCCA-3' \\
\hline \multirow[t]{2}{*}{ Megalin } & Fw & 5'-GATGCTGTTGCTGGCGATCG-3' \\
\hline & $\mathrm{Rv}$ & 5'-CATTGTCACAGCGAAAATTCCCAC-3' \\
\hline \multirow[t]{2}{*}{ MnSOD } & Fw & 5'-ССТСССТGACCTGCCTTACGACTA-3' \\
\hline & $\mathrm{Rv}$ & 5'-TTCAGATTGTTCACGTAGGTCGCG-3' \\
\hline \multirow[t]{2}{*}{ NF- $\mathrm{KB}(\mathrm{p} 105)$} & Fw & 5'-CATGCCAACGCCCTCTTCGA-3' \\
\hline & $\mathrm{Rv}$ & 5'-TGTCCCCGTTCTCATCCTGCAC-3' \\
\hline \multirow[t]{2}{*}{ PMCA-1 } & FW & 5'-GTGTGTGGTGTTAGTGACGG-3' \\
\hline & $\mathrm{Rv}$ & 5'-GTACCTGAAAGAAGCAAGGG-3' \\
\hline \multirow[t]{2}{*}{ PMCA-2 } & Fw & 5'-AAGGAGACATATGGGGAC-3' \\
\hline & $\mathrm{Rv}$ & 5'-TTCACCTTCATCTTCTGC-3' \\
\hline \multirow{2}{*}{ PMCA-3 } & Fw & 5'-CACAGCCTTCAATGACTG-3' \\
\hline & $\mathrm{Rv}$ & 5'-CСТTCCATGACATGAGTG-3' \\
\hline \multirow[t]{2}{*}{ Synaptotagmin V } & Fw & 5'-TGACTTTGACAGGTTCTCTCGCC-3' \\
\hline & $\mathrm{Rv}$ & 5'-AGGATGCACTCCCTGGGGAA-3' \\
\hline \multirow[t]{2}{*}{ Tap1 } & Fw & 5'-ACTTGCCTCGTTCCGAAAGCTG-3' \\
\hline & $\mathrm{Rv}$ & 5'-CGAAGGCATCTAAGCGACTGTTC-3' \\
\hline
\end{tabular}

Fw, forward (sense) primer; Rv, reverse (antisense) primer. All amplicons were in the size ranging from 95-125 bp

following PCR reaction. After ligation to the adaptors, the RFDD templates were purified by silica-gel columns. Finally, the RFDD templates were quantified by fluorimetric assay and digested again by TaqI in order to avoid amplificaton of nondesired fragments. The two silica-gel purification steps greatly increased the resolution of the final cDNA restriction fragment pattern (unpublished observation).

The RFDD fragments were amplified with an IR800-fluorescence-labelled "plus primer" (5'-ACTGGTCTCGTAGACTGCG-3') complementary to the EP adaptor sequence in combination with a "minus primer" (5'-ATGAGTCCTGACCGAN-NN$\left.3^{\prime}\right)$ recognising the SD adaptor sequence, and the three extending variable nucleotides behind the adaptor junction into the cDNA fragment. The combination of these three variable positions with the four possible bases (AGCT) results in 64 different minus primers. Thus, for a complete gene expression profile, 64 separate PCR reactions must be performed. Because the adaptors can bind to both cohesive ends, an individual TaqI fragment can be characterised by two PCR reactions using different minus primers with corresponding 3-base sequences for the sense and antisense strand. Each PCR reaction with a specific "minus primer" amplified 50-250 different fragments that were further analysed for band intensities and fragment size. PCR reactions were done in a cycler using a hot start to avoid unspecific prim- ing (Master-cycler gradient, Eppendorf, Hamburg, Germany). The RFDD templates were amplified with the following profile: initial denaturation at $94{ }^{\circ} \mathrm{C}$ for $1 \mathrm{~min}$, followed by 10 touchdown cycles at $94{ }^{\circ} \mathrm{C}$ for $30 \mathrm{~s}$, at $60{ }^{\circ} \mathrm{C}$ for $30 \mathrm{~s}$ for the first annealing cycle with a consecutive reduction of the annealing temperature by $0.5{ }^{\circ} \mathrm{C}$ in each cycle, and finally at $72{ }^{\circ} \mathrm{C}$ for $1 \mathrm{~min}$. Thereafter, 25 cycles were done with the following profile: $94{ }^{\circ} \mathrm{C}$ for $30 \mathrm{~s}, 55^{\circ} \mathrm{C}$ for $30 \mathrm{~s}$, and $72{ }^{\circ} \mathrm{C}$ for $1 \mathrm{~min}$, followed by a final elongation step at $72{ }^{\circ} \mathrm{C}$ for $5 \mathrm{~min}$. Finally, the PCR products were resolved on a 6\% PAGE with an automatic sequencer (Gene Readir 4200, Li-cor, Lincoln, Neb., USA). A standard size marker (50-700 bp) was run in parallel.

Real Time RT-PCR. mRNA from RINm5F cells was reversetranscribed using oligo dT primer. Expression of selected genes was quantified by the QuantiTec SYBR Green technology (Qiagen), which uses a fluorescent dye that binds only double-stranded DNA. The reactions were carried out using the microplate-based DNA Engine Opticon fluorescence detection system (Biozym Diagnostik, Hess. Oldendorf, Germany). A total volume of $25 \mu \mathrm{l}$ was used for the PCR reactions. Samples were first denatured at $94{ }^{\circ} \mathrm{C}$ for $2 \mathrm{~min}$ followed by up to 40 PCR cycles. Each PCR cycle comprised a denaturation at $94{ }^{\circ} \mathrm{C}$ for $30 \mathrm{~s}$, an annealing at 62 to $65{ }^{\circ} \mathrm{C}$ for $30 \mathrm{~s}$, and an 
Table 2. Differentially expressed genes obtained by RFDD-PCR after exposure of insulin-producing cells to IL-1 $\beta$ alone or a combination of cytokines

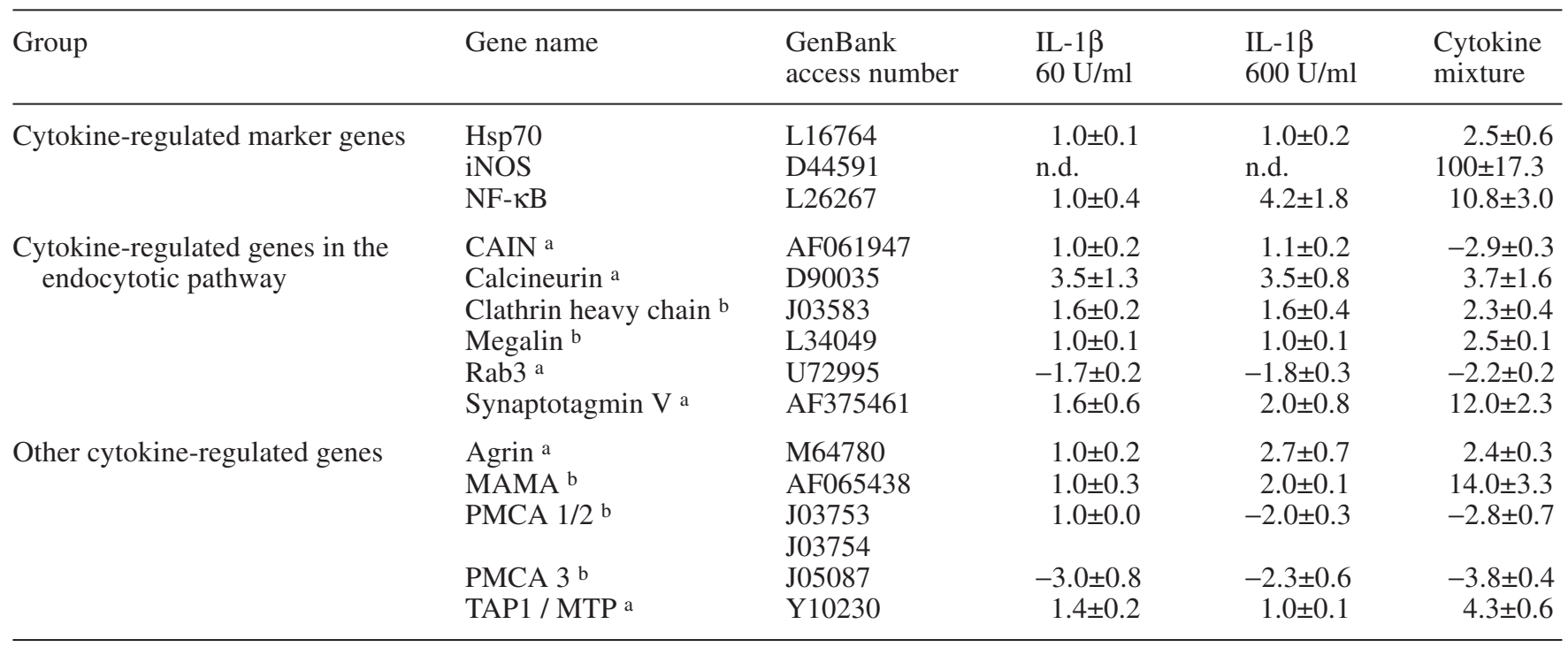

Insulin-producing RINm5F cells were treated as described in Materials and methods. Data were obtained by means of restriction fragment differential display PCR. Results are presented as fold increases (positive values) or decreases (negative values) compared against control values from cells incubated without cytokines, and represent mean values \pm SEM of three independent experiments. A value of 1.0 indicates identity with the control value. Results were considered different

extension at $72{ }^{\circ} \mathrm{C}$ for $30 \mathrm{~s}$. Each PCR amplification was done in triplicate. The optimal parameters for the PCR reactions were empirically defined. The purity of the amplified PCR products was verified by melting curves. The sequences of the primers are presented in Table 1. $\beta$-Actin was used as the reference gene. Real time RT-PCR analyses were done on separate samples from cytokine-exposed RINm5F cells, which were not identical to the samples used for RFDD analyses.

Data analysis. In the RFDD-PCR experiments, the molecular weights of the fragments and the band intensities were calculated using a gel analysis software (Gel-Pro Analyzer 3.1, Media Cybernetics, Silver Spring, Md., USA). Defined fluorescently labelled molecular weight markers (50-700 bp sizing standard, Li-cor) allowed a determination of restriction fragment size with an accuracy of $\pm 2 \mathrm{bp}$. The intensity of the bands was expressed as the density of pixels per line and per area of the bands. The normalisation of the samples was made by global scaling, attributing an arbitrary value of 100 to the total intensity of the lane. The genes encoded by the differentially expressed fragments in the RFDD-PCR were identified using a database (displaySEQ, Qbiogene) with the genome of Rattus norvegicus as the reference. Fragment-coding genes with cytokine-modified expression levels in the RFDD-PCR at least two-fold higher or lower than in the control were defined as differentially expressed. The analysis of the Real Time RT-PCR data was done using the specific Q-Gene analysis program [24]. The data are expressed as means \pm SEM. Statistical analyses were done with ANOVA followed by Dunnett's test for multiple comparisons using the Prism analysis program (Graphpad, San Diego, Calif., USA). when the mean fold change was greater than 2.0. n.d., not detectable.

a These genes have been described as being regulated by cytokines in microarray publications $[8,9,10,12]$ or in the beta cell microarray database (http://jdrf.systemsbiology.org/cgi-bin/ enter_bcgb.cgi).

$\mathrm{b}$ These genes have not been described as being regulated by cytokines

\section{Results}

Restriction fragment differential display PCR method for identification of cytokine-regulated genes. Exposure of insulin-producing RINm5F cells to cytokines resulted in an altered gene expression pattern. Stimulation with either IL-1 $\beta$ alone $(60$ or $600 \mathrm{U} / \mathrm{ml})$ or with a combination of cytokines $(60 \mathrm{U} / \mathrm{ml}$ IL-1 $\beta$, $185 \mathrm{U} / \mathrm{ml}$ TNF- $\alpha$, and $14 \mathrm{U} / \mathrm{ml}$ IFN- $\gamma$ ) modulated the expression of several genes in RINm5F cells (Table 2 and Electronic Supplementary Material). From the 38 genes modulated by the IL- $1 \beta$ and/or cytokine mixture, 14 genes of special interest are presented in Table 2. The remaining 24 cytokine-regulated genes can be accessed as Electronic Supplementary Material (URL beneath Abstract).

The time point of our study $(6 \mathrm{~h})$ was chosen in agreement with previous works indicating that early and relevant changes of the gene expression profile were particularly evident $6 \mathrm{~h}$ after cytokine exposure $[10,25]$. About 3200 transcripts could be identified by RFDD-PCR in RINm5F cells using combinations of 64 different plus primers and one universal minus primer. Computer-aided analysis of all RFDD results was done using stringent parameters. Representative gels for selected genes are shown in Figure 1. Notably, the depicted gels comprise only a small area of the entire gel. Original gel runs have a virtual size of approximately $35 \times 350 \mathrm{~cm}$ and show a complex expression pattern of 

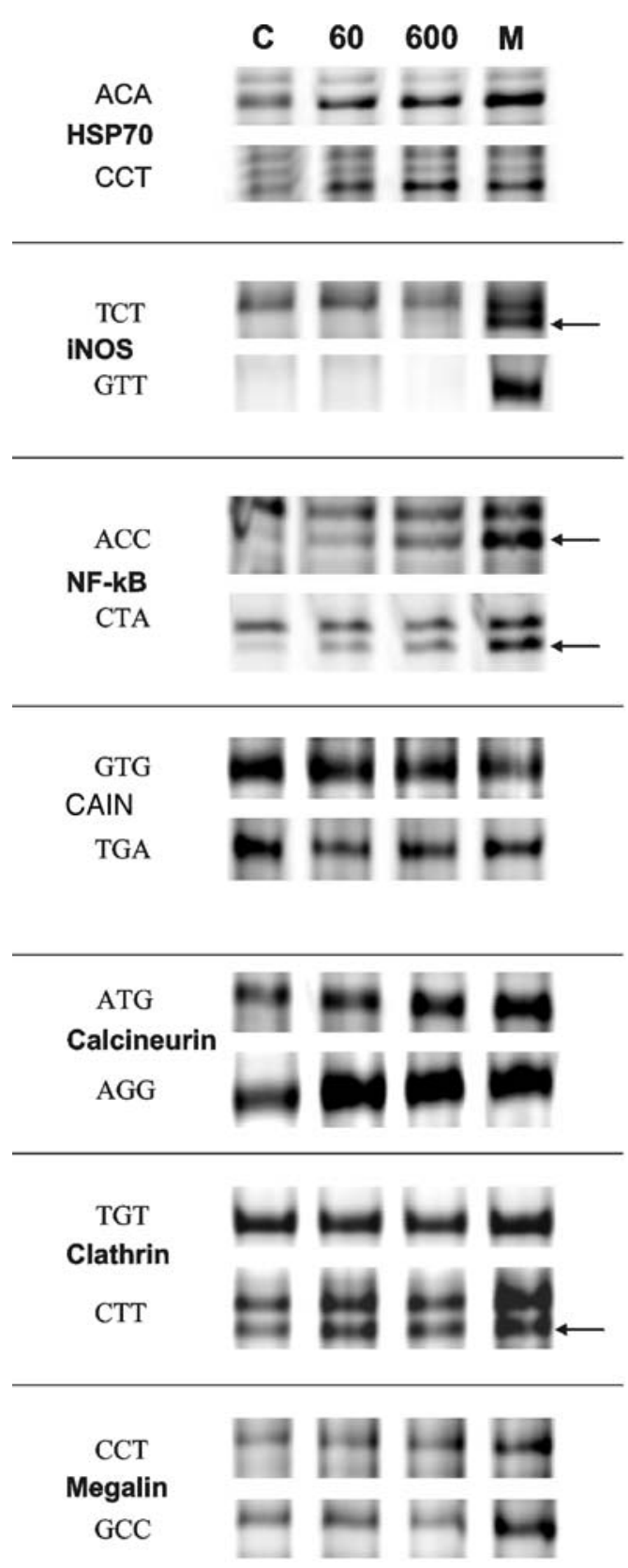

Fig. 1. Identification of cytokine-regulated genes by restriction fragment differential display (RFDD) PCR after exposure of insulin-producing cells to IL- $1 \beta$ alone or a combination of cytokines. Insulin-producing RINm5F cells were exposed for $6 \mathrm{~h}$ either to $60 \mathrm{U} / \mathrm{ml}$ of IL-1 $\beta$ (lane 60), $600 \mathrm{U} / \mathrm{ml}$ of IL-1 $\beta$ (lane 600$)$, or a cytokine mixture $(60 \mathrm{U} / \mathrm{ml} \mathrm{IL}-1 \beta, 185 \mathrm{U} / \mathrm{ml}$ TNF- $\alpha, 14 \mathrm{U} / \mathrm{ml}$ IFN- $\gamma$; lane M), and compared to cells incubated without cytokines (control condition; lane C). After lysis of the cells and extraction of the mRNA, identification of expressed genes was done by restriction fragment differential display PCR. Representative bands from three experiments are shown, with duplicate sense and antisense probes for each

amplified restriction fragments. The absolute intensities of the lanes were linear between 0 and $6.5 \times 10^{4}$ fluorescence units. For background correction, the intensities of each lane were normalised by the GelPro software routines for consecutive quantification of selected
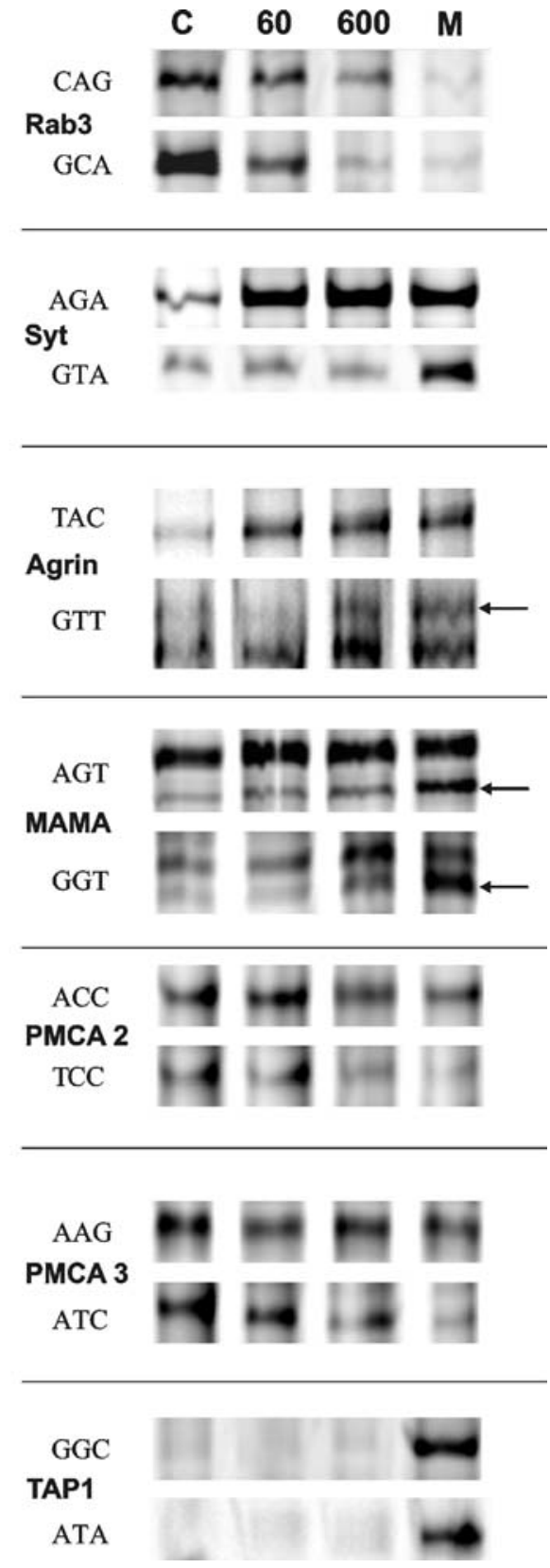

gene. HSP70, heat shock protein 70; iNOS, inducible nitric oxide synthase; NF- $\mathrm{B}$, nuclear factor kappa B; CAIN, calcineurin inhibitor; Rab3, Rab3 GDP/GTP exchange protein mRNA; Syt, synaptogamin V; MAMA, murine adherent macrophage protein mRNA; PMCA, plasma membrane calcium ATPase; TAP1, transporter antigen peptides 1 and/or multidrug resistance protein (from $\mathrm{ABC}$ transporter family). The two lanes for each gene represent the same RFDD cDNA fragment amplified by two different specific primers annealing to the sense and antisense strand of the gene. The arrows point to the specific RFDD amplification product when multiple bands are visible in the representative part of the gel

bands representing differentially expressed genes (Table 2). We confirmed the results obtained by the multiplex RFDD-PCR, as a semi-quantitative method for the evaluation of gene expression, by quantitative real-time RT-PCR analysis (Table 3). 
Table 3. Real-time RT-PCR gene expression quantification of selected genes detected by RFDD-PCR after exposure of insulinproducing cells to IL-1 $\beta$ alone or a combination of cytokines

\begin{tabular}{|c|c|c|c|}
\hline Gene name & IL-1ß 60 U/ml & IL-1及 600 U/ml & Cytokine mixture \\
\hline Hsp70 & $5.3 \pm 1.1^{\mathrm{b}}$ & $4.6 \pm 0.7^{b}$ & $7.7 \pm 1.6^{b}$ \\
\hline iNOS & $15.2 \pm 4.1^{\mathrm{a}}$ & $35.0 \pm 11.5^{\mathrm{a}}$ & $166.3 \pm 30.2^{b}$ \\
\hline CAIN & $-1.3 \pm 0.2$ & $-1.1 \pm 0.2$ & $-3.3 \pm 0.0^{\mathrm{a}}$ \\
\hline Calcineurin & $3.5 \pm 0.4^{b}$ & $4.5 \pm 0.8^{b}$ & $5.2 \pm 0.9^{b}$ \\
\hline Clathrin heavy chain & $2.4 \pm 0.2^{b}$ & $3.5 \pm 0.3^{b}$ & $5.6 \pm 0.4^{b}$ \\
\hline Synaptotagmin V & $2.4 \pm 0.3^{b}$ & $3.6 \pm 0.4^{b}$ & $6.7 \pm 0.9^{b}$ \\
\hline Agrin & $3.8 \pm 0.2^{b}$ & $4.0 \pm 0.1^{\mathrm{b}}$ & $5.2 \pm 0.1^{\mathrm{b}}$ \\
\hline MAMA & $2.3 \pm 0.6$ & $2.3 \pm 0.6$ & $5.4 \pm 1.8^{\mathrm{a}}$ \\
\hline PMCA 2 & $-1.5 \pm 0.1^{\mathrm{a}}$ & $-2.6 \pm 0.1^{b}$ & $-2.0 \pm 0.1^{b}$ \\
\hline PMCA 3 & $-1.2 \pm 0.1$ & $-2.2 \pm 0.1^{\mathrm{b}}$ & $-2.2 \pm 0.1^{\mathrm{a}}$ \\
\hline Tap1/MTP & $5.5 \pm 0.7^{a}$ & $6.4 \pm 1.5^{\mathrm{a}}$ & $30.1 \pm 9.5^{\mathrm{a}}$ \\
\hline
\end{tabular}

Insulin-producing RINm5F cells were treated as described (Materials and methods). Quantification was done by means of quantitative real-time RT-PCR using the SYBR green I system. Results are presented as fold increases (positive values) or decreases (negative values) compared against control values from cells incubated without cytokines, and represent mean values \pm
SEM of three to five independent experiments. The expression level of the housekeeping gene $\beta$-actin did not change significantly. ${ }^{\mathrm{a}} p<0.05,{ }^{\mathrm{b}} p<0.01$ compared to RINm5F cells without cytokine exposure after normalisation to $\beta$-actin (ANOVA plus Dunnett's post test)

of RINm5F cells to both a low and a high concentration of IL-1 $\beta$ increased the MnSOD mRNA levels by $8.3 \pm 1.4$ and $10.1 \pm 1.5$-fold respectively $(n=5)$. Cells exposed to the cytokine mix also presented a large increase in MnSOD expression (7.4 \pm 1.2 fold, $n=5$ ). The affected marker gene expression shows that the cytokines were biologically active. No differences were found in $\beta$-actin gene expression among the three experimental groups (Table 3).

Cytokine-regulated genes of the endocytotic pathway. Using the RFDD-PCR gene expression screening technique, we were able to identify within the 38 cytokine-regulated genes a functional cluster coding for proteins involved in the regulation of the endocytotic pathway. These were the genes for the calcineurin inhibitor $(C A I N)$, for calcineurin, for clathrin (heavy chain), for megalin, for Rab3 GDP/GTP exchange protein mRNA, and for synaptotagmin V (Fig. 1 and Table 2). However, while the CAIN and Rab3 gene expression were reduced, the expression of the other four genes was increased (Fig. 1 and Table 2). Again, the cytokine effects were clearly evident using this semi-quantitative approach, especially after exposure of the cells to the cytokine mixture (Fig. 1 and Table 2).

These results were confirmed by quantifying the gene expression of these six genes potentially involved in the endocytotic pathway in quantitative real time RT-PCR measurements (Table 3 ). While a significant suppression of the CAIN gene expression was evident only after the cells were incubated with the cytokine mixture, a significant, albeit weaker, de- 
crease of the gene expression of Rab3 was also evident after the cells were exposed to IL-1 $\beta$ (60 and $600 \mathrm{U} / \mathrm{ml}$ ) (Table 3). The increase of the gene expression of calcineurin, clathrin (heavy chain), megalin, and synaptotagmin $\mathrm{V}$ was also confirmed by quantitative real time RT-PCR (Table 3).

Other cytokine-regulated genes. The gene expression levels of several other single genes were also affected by cytokine treatment (Fig. 1 and Table 2). The expression of the genes for the extracellular matrix protein agrin, for the murine adherent macrophage protein (MAMA), and for the transport-associated protein 1 (TAP1, undistinguishable from the murine transport protein $[M T P])$ were up-regulated by cytokines. Again, the cytokine effects were clearly evident using this semi-quantitative approach predominantly after exposure of the cells to the cytokine mixture (Fig. 1 and Table 2). On the other hand, the genes for the plasma membrane calcium ATPase (PMCA) 1 or 2, which cannot be discerned by the RFDD method since they have the same Taq I restriction site, and for PMCA 3 were down-regulated by cytokine treatment. These results were confirmed using quantification of the gene expression in quantitative real time RTPCR measurements (Table 3). PMCA 2 and PMCA 3 mRNA levels were down-regulated in all three conditions tested. This is especially evident in the higher concentration of IL-1 $\beta$ and the cytokine mixture. The $P M C A 1$ gene was not modulated by cytokine treatment (data not shown).

\section{Discussion}

Cytokines mediate toxicity to insulin-producing cells through complex signal cascades, which affect the gene expression profile of the cells in a critical balance between death and survival. In this study, we used an automated RFDD-PCR gene expression screening approach to characterise changes of gene expression in insulin-producing RINm5F cells after exposure to toxic cytokines. The RFDD-PCR proved to be a reliable method for analysing gene expression in RINm5F cells because each gene was verified by two independent amplifications of the restriction fragments and confirmed by real-time RT-PCR analysis. However, the RFDD-PCR also has some limitations. Firstly, the RFDD analysis requires at least two TaqI restriction sites within the cDNA for the ligation of the adaptors to the cohesive ends. Secondly, the RFDD template amplification is a multiplex PCR method, which has variant efficiencies for the different templates and specific primers, although detection of the amplification products shows linearity over four magnitudes of fluorescence units. These limitations became evident in the differences in the band intensities for the Syt transcripts (Fig. 1) and also in the differences between RFDD analysis and real-time RT-PCR quantification of the $i N O S$ gene after exposure to IL-1 $\beta$ alone (Fig. 1 and Table 3 ). Furthermore, the number of the identified cytokine-regulated genes is lower in comparison to the microarray method. The latter has the advantage of not depending on a multiplex PCR amplification. On the other hand, the RFDD-PCR methodology generally has the potential to detect genes that are not covered by microarrays and is also a versatile technique for samples from species for which a microarray chip is not available. Nevertheless, the standard errors of our RFDD-PCR data indicate that this method showed a good reproducibility for the identification of cytokine-regulated genes in insulin-producing cells. The present gene-expression data are complementary to microarray studies upon INS-1 cells $[10,12]$ and primary beta cells [9, 11], and contribute to dynamic databases of cytokineregulated genes. Knowledge of these genes may serve as a basis for functional studies on the development of novel strategies to protect beta cells against autoimmune destruction. Within these databases, functionally related gene clusters attract special attention because these genes mostly code for signal pathways that are highly regulated and therefore represent a potential target for protective intervention. Apart from the cytokine-induced marker genes $i N O S, N F-\kappa B$ and $H s p 70$, which are known to be up-regulated by previous microarray and functional studies, a functionally related endocytotic pathway gene cluster was affected in RINm5F cells. This group of genes, related to endocytosis, has not been described so far as a functional cluster in the context of cytokine-regulated genes in pancreatic beta cells, but deserves more comprehensive consideration due to a possible impact upon the cell sensitivity towards cytokines.

The endocytotic process is a complex mechanism in which several proteins are involved (for review see $[19,28])$. In our study, this pathway proved to be regulated by cytokines. It has been shown that the cytokines IL- $1 \beta$ and TNF- $\alpha$ increased the rate of endocytosis in liver endothelial cells, an effect that is apparently counteracted by NO [16, 29]. One of the most important components of the endocytotic pathway is clathrin, a triskelion-shaped protein that oligomerises to form endocytotic pits [28]. The RFDD-PCR as well as real-time RT-PCR analysis showed that mRNA levels coding for the clathrin heavy chain were increased in insulin-producing RINm5F cells after exposure to pro-inflammatory cytokines. In pancreatic beta cells, clathrin is involved in the removal of proteases from maturing secretory insulin granules by the endosomal system but not in the sorting or processing of proinsulin or in regulated exocytosis of secretory granules [30, 31].

Many proteins may interact with or are dependent on clathrin action [28]. Megalin is a peripheral glycoprotein belonging to the LDL receptor family that 
mediates clathrin-dependent endocytosis of ligands in various polarised epithelia [32, 33]. It was first described in the kidney but has a ubiquitous tissue distribution [33], and is abundantly expressed in clathrincoated pits [34, 35]. Megalin mRNA expression was up-regulated by $250 \%$ in RINm5F cells after cytokine exposure. The observed strong correlation between the cytokine-dependent increase in both clathrin and megalin mRNA levels, as shown by the present gene expression analyses, indicates the operation of a "functional gene cluster", related to endocytosis.

Megalin is a multifactorial binding receptor for a number of molecules such as protein-associated vitamins, lipids, and hormones [33, 36], vitamin D carrier protein [37, 38] and advanced glycation end-products, which are up-regulated in diabetes [39], but also for insulin itself [34]. Therefore, megalin may also act as a scavenger for cytokine molecules in the endocytotic process. The megalin-binding ligand could be delivered to endosomes and later to lysosomes, while megalin could be recycled to the cell membrane, as previously described $[34,35]$. Thus the up-regulation of key structures of the endocytotic pathway in insulin-producing cells may function as negative feedback, aimed at decreasing sensitivity towards proinflammatory cytokines even at the receptor level, thereby blocking complex intracellular signalling pathways.

Phosphorylation/dephosphorylation cycles seem to be the key mechanisms by which cells control the assembly of the endocytotic machinery in clathrin-mediated endocytosis, which are known also to be $\mathrm{Ca}^{2+}$ dependent $[40,41]$. Calcineurin is a $\mathrm{Ca}^{2+} /$ calmodulindependent protein phosphatase involved in various signalling pathways of vesicular trafficking [42]. Notably, inhibitors of calcineurin counteracted the stimulatory effect of inositol hexakisphosphate on endocytosis in insulin-producing cells [43], suggesting that calcineurin might act as a modulator of the endocytotic process in the beta cell. Furthermore, calcineurin has been regarded as a calcium sensor for endocytosis, similar to synaptotagmin for exocytosis. Disruption of the calcineurin-dynamin 1 interaction inhibits clathrin-mediated endocytosis [44]. Our differential display data show that calcineurin expression was increased in RINm5F cells exposed to IL- $1 \beta$ or to a combination of cytokines (IL- $1 \beta+$ TNF- $\alpha+$ IFN- $\gamma$ ), supporting a possible role of calcineurin in cytokine-induced endocytosis. This is in agreement with the up-regulation of this gene reported by microarray analysis of INS-1 cells after a 2 -h exposure to IL-1 $\beta$ and IFN- $\gamma$ [10]. Recent studies have shown that calcineurin affects $\mathrm{Ca}^{2+}$-dependent signalling mechanisms in beta cell apoptosis [45], and inhibitors of calcineurin are able to prolong survival of allograft islet transplants [45, 46, 47, 48]. This effect may be at least partly mediated through an ameliorated activation of $N F-\kappa B$ via a $\mathrm{Ca}^{2+}$-dependent mechanism [49].
In line with the effects of cytokines upon genes of the endocytotic pathway, we also found a decrease of CAIN expression through exposure to the IL-1 $\beta$ and cytokine combination. CAIN (also known as Cabdin) acts as a physiological non-competitive inhibitor of calcineurin and both proteins are components of the endocytotic machinery [50]. Overexpression of CAIN in HEK293 cells blocked endocytosis [51]. Thus decreased levels of CAIN could also favour endocytosis in insulin-producing cells.

Another cytokine-sensitive gene from the endocytotic cluster family that was seen to be modified in our analysis was the neuronal form of synaptotagmin (synaptotagmin V). Synaptotagmin was up-regulated by cytokines in RINm5F cells, in agreement with a recent microarray analysis in INS-1 cells [12]. Synaptotagmin is an integral vesicle membrane protein generally associated with exocytosis and usually referred to as a calcium sensor $[52,53,54]$. However, several lines of evidence suggest that synaptotagmin might also be essential for endocytosis. Synaptotagmin recruits the AP-2 complex to the vesicle and thus properly initiates the endocytotic process $[41,55]$. Furthermore, transfection studies using truncated forms of synaptotagmin indicate that a lack of the $\mathrm{C} 2 \mathrm{~B}$-domain of the protein inhibits the formation of clathrin-coated pits in fibroblasts [56], pointing to a broad spectrum of synaptotagmin actions. Therefore, an increase in synaptotagmin levels, as indicated by our results, may contribute to an increase in clathrin-mediated endocytosis.

The observed cytokine-induced down-regulation of PMCA 2 and 3 in RINm5F cells is also in agreement with the effects on endocytotic pathways. These proteins interfere with calcium buffering. Their low levels could help to maintain increased $\left[\mathrm{Ca}^{2+}\right]_{\mathrm{i}}$ favouring the activation of calcineurin and thereby increasing the rate of endocytosis [57]. Interestingly, PMCAs seem to be involved in cell death processes [58].

The Rab3 GDP/GTP exchange protein mRNA was down-regulated by cytokines in RINm5F cells. This protein is involved in regulated exocytosis [59], but can also interact with $\mathrm{N}$-ethylmaleimide-sensitive factor, which is present in the membranes of endosomes, the clathrin-coated vesicles and the Golgi apparatus, thereby affecting the process of intracellular trafficking $[60,61,62]$. Interestingly, the MAP-kinase activating death domain (the human gene ortholog to rat Rab3 GDP/GTP exchange protein gene) is involved in the Type 1 TNF receptor pathway, providing a link between cytokine and Rab3 gene expression [63]. Therefore, a down-regulation of the Rab3 GDP/GTP exchange protein gene expression could also affect the function of TNF receptors in insulin-producing cells.

In addition to the genes that might directly act in endocytosis and trafficking processes, we found three other genes that were of interest in RINm5F cells exposed to cytokines and were possibly indirectly relat- 
ed to the endocytotic pathway. Agrin, a basal lamina protein involved in the proper formation of acetylcholine receptors in muscle cells [64], was up-regulated by IL- $1 \beta$ and a cytokine mixture. The agrin-dependent clustering of plasma membrane receptors also involves calcineurin [65], and this protein may control the clustering of synaptotagmin [66]. Thus agrin could play an integrative role in the cytokine-regulated endocytotic pathway in insulin-producing cells. In RINm5F and INS-1 cells, agrin was up-regulated 8 , 12 and $24 \mathrm{~h}$ after exposure to IL- $1 \beta$ alone or a combination of IL- $1 \beta$ and IFN- $\gamma[8,10]$.

The Tapl/mtpl gene showed a 30-fold up-regulation in RINm5F cells after exposure to the cytokine combination in agreement with microarray studies upon rat pancreatic beta cells $[9,10]$. These proteins are involved in the transport of molecules into the lumen of the endoplasmic reticulum and antigen presentation [67, 68]. They may thus participate in the process of intracellular trafficking after cytokine exposure, a phenomenon of potential relevance for the expression of chemoattractants by beta cells in response to the pro-inflammatory stimulus [11].

$M A M A$, another interesting gene, which was up-regulated by cytokines, has so far not been described as a cytokine-sensitive gene in insulin-producing cells. This protein belongs to the macrophage scavenger receptor gene family, which plays an important role in neurodegenerative processes in response to pro-inflammatory stimuli [69]. Thus the MAMA protein may be linked to signal pathways of cytokine toxicity.

Endocytosis is a common mechanism used by cells to internalise cell membrane receptors. The downregulation of cytokine receptors through internalisation can help to decrease the beta cell toxicity of proinflammatory cytokines. Internalisation of the IL- $1 \beta$ receptor has been described in different cell types, where the internalised receptor accumulated in the cytosol and could be recycled to the plasma membrane $[70,71,72]$. Receptor-mediated endocytosis was also shown for IFN- $\gamma$, but in contrast to the recycling of the IL-1 $\beta$ receptor, a lysosomal ligandreceptor degradation occurred after internalisation [73]. Endocytotic internalisation of cytokine receptors is also modulated by NO, which had a negative effect upon TNF receptor endocytosis in dendritic cells [74, 75]. To our knowledge, the internalisation of cytokine receptors has not been investigated systematically in pancreatic beta cells by functional studies. However, the relevance of endocytotic signalling pathways has been recently shown for insulin-producing HIT cells with an inositol hexakisphosphate regulated endocytosis [43]. Our gene expression data are therefore the first step in verifying the relevance of the endocytic pathway within the signalling pathways of cytokine toxicity by functional studies. This will have to be supplemented by measurements of protein expression, endocytosis rates and expression of cytokine receptors

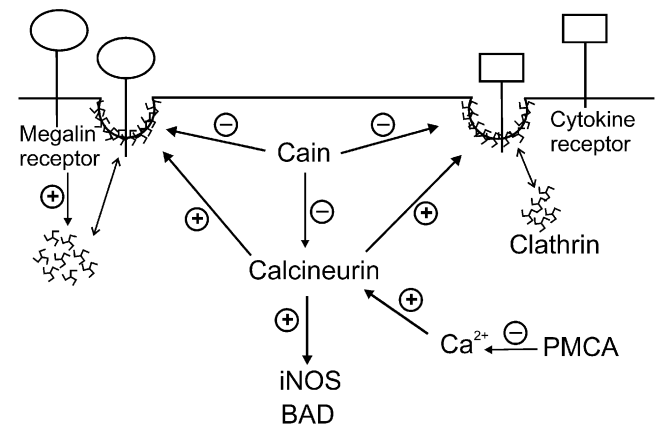

Fig. 2. Effects of cytokines upon the expression of genes affecting the endocytotic pathway in insulin-producing cells. Cytokine receptor internalisation can be modulated by mechanisms which stimulate $(+)$ or inhibit $(-)$ endocytotic signalling pathways. Cytokine-induced up-regulation of clathrin and megalin expression favours the internalisation of cytokine receptors and ligands through formation of clathrin-coated pits. Calcineurin and synaptotagmin could also act as positive modulators of the endocytotic machinery. On the other hand, the calcineurin inhibitor CAIN and the $\mathrm{Ca}^{2+}$ ATPases (PMCA) were down-regulated by cytokines, thereby indirectly stimulating endocytosis of cytokine receptors. From the gene expression analyses it is evident that genes capable of increasing the endocytotic process were up-regulated by cytokines in insulin-producing cells, whereas genes inhibiting the endocytotic pathway were down-regulated. BAD, bcl-x, bcl-2-associated death promoter homolog

in dependence upon exposure to pro-inflammatory cytokines.

Through RFDD-PCR, we have demonstrated that cytokine exposure of insulin-producing RINm5F cells affected gene expression of a functional gene cluster of endocytotic signalling pathways in a way that favours the internalisation of cytokine receptors. A hypothetical model, based on our data, is shown in Figure 2. Thus, while genes that increase the endocytotic process are up-regulated by cytokines, inhibitory genes of the endocytotic pathway are down-regulated. The cytokine-mediated up- and down-regulation of endocytotic genes, as observed in the present RFDDPCR analyses, might be an interesting and novel mechanism to protect insulin-producing cells against the deleterious effects of cytokines. This, and the information on other modified genes described above, provides new insights into the complex networks of cytokine signalling in beta cells during the early stages of autoimmune diabetes.

Acknowledgements. This study is part of the $\mathrm{PhD}$ thesis by K.L.A. Souza, who was recipient of a grant from the European Union within the ALFA (Amérique Latine - Formation Académique) Programme on leave from the University of Maringá (Maringá, Brazil) and was supported by the Brazilian National Council for Science and Technological Development. M. Tiedge was supported by the Juvenile Diabetes Research Foundation International as a member of the "JDRF Centre for Prevention of Beta Cell Destruction in Europe" (grant number 4-2002-457). The skillful technical assistance of D. Lischke is gratefully acknowledged. 


\section{References}

1. Mandrup-Poulsen T (1996) The role of interleukin-1 in the pathogenesis of IDDM. Diabetologia 39:1005-1029

2. Rabinovitch A, Suarez-Pinzon WL (1998) Cytokines and their roles in pancreatic islet beta-cell destruction and insulin-dependent diabetes mellitus. Biochem Pharmacol 55:1139-1149

3. Eizirik DL, Mandrup-Poulsen T (2001) A choice of death - the signal-transduction of immune-mediated betacell apoptosis. Diabetologia 44:2115-2133

4. Eizirik DL, Darville MI (2001) beta-cell apoptosis and defense mechanisms: lessons from type 1 diabetes. Diabetes 50 [Suppl 1]:S64-S69

5. Eizirik DL, Flodstrom M, Karlsen AE, Welsh N (1996) The harmony of the spheres: inducible nitric oxide synthase and related genes in pancreatic beta cells. Diabetologia 39:875-890

6. Lortz S, Tiedge M, Nachtwey T, Karlsen AE, Nerup J, Lenzen S (2000) Protection of insulin-producing RINm5F cells against cytokine-mediated toxicity through overexpression of antioxidant enzymes. Diabetes 49:11231130

7. Azevedo-Martins AK, Lortz S, Lenzen S, Curi R, Eizirik DL, Tiedge M (2003) Improvement of the mitochondrial antioxidant defense status prevents cytokine-induced nuclear factor-kappaB activation in insulin-producing cells. Diabetes 52:93-101

8. Rieneck K, Bovin LF, Josefsen K, Buschard K, Svenson M, Bendtzen K (2000) Massive parallel gene expression profiling of RINm5F pancreatic islet beta-cells stimulated with interleukin-1beta. Apmis 108:855-872

9. Cardozo AK, Heimberg H, Heremans Y et al. (2001) A comprehensive analysis of cytokine-induced and nuclear factor-kappa B-dependent genes in primary rat pancreatic beta-cells. J Biol Chem 276:48879-48886

10. Cardozo AK, Kruhoffer M, Leeman R, Orntoft T, Eizirik DL (2001) Identification of novel cytokine-induced genes in pancreatic beta-cells by high-density oligonucleotide arrays. Diabetes 50:909-920

11. Rasschaert J, Liu D, Kutlu B et al. (2003) Global profiling of double stranded RNA- and IFN-gamma-induced genes in rat pancreatic beta cells. Diabetologia 46:1641-1657

12. Kutlu B, Cardozo AK, Darville MI et al. (2003) Discovery of gene networks regulating cytokine-induced dysfunction and apoptosis in insulin-producing INS-1 cells. Diabetes 52:2701-2719

13. Gravesen A, Warthoe P, Knochel S, Thirstrup K (2000) Restriction fragment differential display of pediocin-resistant Listeria monocytogenes 412 mutants shows consistent overexpression of a putative beta-glucoside-specific PTS system. Microbiology 146:1381-1389

14. Montaner LJ, da Silva RP, Sun J et al. (1999) Type 1 and type 2 cytokine regulation of macrophage endocytosis: differential activation by IL-4/IL-13 as opposed to IFNgamma or IL-10. J Immunol 162:4606-4613

15. Martinez I, Sveinbjornsson B, Vidal-Vanaclocha F, Asumendi A, Smedsrod B (1995) Differential cytokinemediated modulation of endocytosis in rat liver endothelial cells. Biochem Biophys Res Commun 212:235-241

16. Martinez I, Sveinbjornsson B, Smedsrod B (1996) Nitric oxide down-regulates endocytosis in rat liver endothelial cells. Biochem Biophys Res Commun 222:688-693

17. Qualmann B, Kessels MM (2002) Endocytosis and the cytoskeleton. Int Rev Cytol 220:93-144

18. Jarousse N, Kelly RB (2001) Endocytotic mechanisms in synapses. Curr Opin Cell Biol 13:461-469
19. Slepnev VI, De Camilli P (2000) Accessory factors in clathrin-dependent synaptic vesicle endocytosis. Nat Rev Neurosci 1:161-172

20. Elsner M, Tiedge M, Guldbakke B, Munday R, Lenzen S (2002) Importance of the GLUT2 glucose transporter for pancreatic beta cell toxicity of alloxan. Diabetologia 45:1542-1549

21. Green LC, Wagner DA, Glogowski J, Skipper PL, Wishnok JS, Tannenbaum SR (1982) Analysis of nitrate, nitrite, and $\left[{ }^{15} \mathrm{~N}\right]$ nitrate in biological fluids. Anal Biochem 126:131138

22. Chomczynski P, Sacchi N (1987) Single-step method of RNA isolation by acid guanidinium thiocyanate-phenolchloroform extraction. Anal Biochem 162:156-159

23. Gravesen A, Sorensen K, Aarestrup FM, Knochel S (2001) Spontaneous nisin-resistant Listeria monocytogenes mutants with increased expression of a putative penicillinbinding protein and their sensitivity to various antibiotics. Microb Drug Resist 7:127-135

24. Muller PY, Janovjak H, Miserez AR, Dobbie Z (2002) Processing of gene expression data generated by quantitative real-time RT-PCR. Biotechniques 32:1372-1374, 1376, 1378-1379

25. Niemann A, Bjorklund A, Eizirik DL (1994) Studies on the molecular regulation of the inducible form of nitric oxide synthase (iNOS) in insulin-producing cells. Mol Cell Endocrinol 106:151-155

26. Corbett JA, Sweetland MA, Wang JL, Lancaster JR Jr, McDaniel ML (1993) Nitric oxide mediates cytokineinduced inhibition of insulin secretion by human islets of Langerhans. Proc Natl Acad Sci USA 90:1731-1735

27. Sekine N, Ishikawa T, Okazaki T, Hayashi M, Wollheim CB, Fujita T (2000) Synergistic activation of NF-kappab and inducible isoform of nitric oxide synthase induction by interferon-gamma and tumor necrosis factor-alpha in INS-1 cells. J Cell Physiol 184:46-57

28. Lafer EM (2002) Clathrin-protein interactions. Traffic 3:513520

29. Asumendi A, Alvarez A, Martinez I, Smedsrod B, VidalVanaclocha F (1996) Hepatic sinusoidal endothelium heterogeneity with respect to mannose receptor activity is interleukin-1 dependent. Hepatology 23:1521-1529

30. Molinete M, Dupuis S, Brodsky FM, Halban PA (2001) Role of clathrin in the regulated secretory pathway of pancreatic beta-cells. J Cell Sci 114:3059-3066

31. Arvan P, Halban PA (2004) Sorting ourselves out: seeking consensus on trafficking in the beta-cell. Traffic 5:53-61

32. Van Praet O, Argraves WS, Morales CR (2003) Co-expression and interaction of cubilin and megalin in the adult male rat reproductive system. Mol Reprod Dev 64:129-135

33. Christensen EI, Birn H (2002) Megalin and cubilin: multifunctional endocytic receptors. Nat Rev Mol Cell Biol 3:256-266

34. Orlando RA, Rader K, Authier F et al. (1998) Megalin is an endocytic receptor for insulin. J Am Soc Nephrol 9:1759-1766

35. Czekay RP, Orlando RA, Woodward L, Lundstrom M, Farquhar MG (1997) Endocytic trafficking of megalin/ RAP complexes: dissociation of the complexes in late endosomes. Mol Biol Cell 8:517-532

36. Moestrup SK, Verroust PJ (2001) Megalin- and cubilinmediated endocytosis of protein-bound vitamins, lipids, and hormones in polarized epithelia. Annu Rev Nutr 21:407-428

37. May P, Bock HH, Herz J (2003) Integration of endocytosis and signal transduction by lipoprotein receptors. Sci STKE 2003:PE12 
38. Hilpert J, Wogensen L, Thykjaer T et al. (2002) Expression profiling confirms the role of endocytic receptor megalin in renal vitamin D3 metabolism. Kidney Int 62:1672-1681

39. Saito A, Nagai R, Tanuma A et al. (2003) Role of megalin in endocytosis of advanced glycation end products: implications for a novel protein binding to both megalin and advanced glycation end products. J Am Soc Nephrol 14:1123-1131

40. Slepnev VI, Ochoa GC, Butler MH, Grabs D, Camilli PD (1998) Role of phosphorylation in regulation of the assembly of endocytic coat complexes. Science 281:821-824

41. McClure SJ, Robinson PJ (1996) Dynamin, endocytosis and intracellular signalling (review). Mol Membr Biol 13:189-215

42. Frantz B, Nordby EC, Bren G et al. (1994) Calcineurin acts in synergy with PMA to inactivate I kappa B/MAD3, an inhibitor of NF-kappa B. Embo J 13:861-870

43. Hoy M, Efanov AM, Bertorello AM et al. (2002) Inositol hexakisphosphate promotes dynamin I-mediated endocytosis. Proc Natl Acad Sci USA 99:6773-6777

44. Lai MM, Hong JJ, Ruggiero AM et al. (1999) The calcineurin-dynamin 1 complex as a calcium sensor for synaptic vesicle endocytosis. J Biol Chem 274:25963-25966

45. Zaitsev SV, Appelskog IB, Kapelioukh IL et al. (2001) Imidazoline compounds protect against interleukin 1beta-induced beta-cell apoptosis. Diabetes 50 [Suppl 1]:S70-S76

46. Adams AB, Shirasugi N, Durham MM et al. (2002) Calcineurin inhibitor-free CD28 blockade-based protocol protects allogeneic islets in nonhuman primates. Diabetes 51:265-270

47. Liu EH, Herold KC (2000) Transplantation of the islets of Langerhans: new hope for treatment of type 1 diabetes mellitus. Trends Endocrinol Metab 11:379-382

48. Chandra J, Zhivotovsky B, Zaitsev S, Juntti-Berggren L, Berggren PO, Orrenius S (2001) Role of apoptosis in pancreatic beta-cell death in diabetes. Diabetes 50 [Suppl 1]: S44-S47

49. Mogensen TH, Melchjorsen J, Hollsberg P, Paludan SR (2003) Activation of NF-kappa B in virus-infected macrophages is dependent on mitochondrial oxidative stress and intracellular calcium: downstream involvement of the kinases TGF-beta-activated kinase 1, mitogen-activated kinase/extracellular signal-regulated kinase kinase 1, and I kappa B kinase. J Immunol 170:6224-6233

50. Lai MM, Luo HR, Burnett PE, Hong JJ, Snyder SH (2000) The calcineurin-binding protein cain is a negative regulator of synaptic vesicle endocytosis. J Biol Chem 275:3401734020

51. Lai MM, Burnett PE, Wolosker H, Blackshaw S, Snyder SH (1998) Cain, a novel physiologic protein inhibitor of calcineurin. J Biol Chem 273:18325-18331

52. Gut A, Kiraly CE, Fukuda M, Mikoshiba K, Wollheim CB, Lang J (2001) Expression and localisation of synaptotagmin isoforms in endocrine beta-cells: their function in insulin exocytosis. J Cell Sci 114:1709-1716

53. Li C, Ullrich B, Zhang JZ, Anderson RG, Brose N, Südhof TC (1995) Ca(2+)-dependent and -independent activities of neural and non-neural synaptotagmins. Nature 375:594-599

54. Saegusa C, Fukuda M, Mikoshiba K (2002) Synaptotagmin $\mathrm{V}$ is targeted to dense-core vesicles that undergo calciumdependent exocytosis in PC12 cells. J Biol Chem 277:24499-24505

55. Zhang JZ, Davletov BA, Südhof TC, Anderson RG (1994) Synaptotagmin I is a high affinity receptor for clathrin AP-2: implications for membrane recycling. Cell 78:751-760

56. Von Poser C, Zhang JZ, Mineo C et al. (2000) Synaptotagmin regulation of coated pit assembly. J Biol Chem 275:30916-30924
57. Sasamura S, Furukawa K, Shiratori M, Motomura S, Ohizumi Y (2002) Antisense-inhibition of plasma membrane $\mathrm{Ca}^{2+}$ pump induces apoptosis in vascular smooth muscle cells. Jpn J Pharmacol 90:164-172

58. Schwab BL, Guerini D, Didszun C et al. (2002) Cleavage of plasma membrane calcium pumps by caspases: a link between apoptosis and necrosis. Cell Death Differ 9:818831

59. Fischer von Mollard G, Stahl B, Li C, Südhof TC, Jahn R (1994) Rab proteins in regulated exocytosis. Trends Biochem Sci 19:164-168

60. Tagaya M, Furuno A, Mizushima S (1996) SNAP prevents $\mathrm{Mg}(2+)$-ATP-induced release of N-ethylmaleimide-sensitive factor from the Golgi apparatus in digitonin-permeabilized PC12 cells. J Biol Chem 271:466-470

61. Robinson LJ, Aniento F, Gruenberg J (1997) NSF is required for transport from early to late endosomes. J Cell Sci 110:2079-2087

62. Han SY, Park DY, Park SD, Hong SH (2000) Identification of Rab6 as an N-ethylmaleimide-sensitive fusion proteinbinding protein. Biochem J 352:165-173

63. Iwasaki K, Toyonaga R (2000) The Rab3 GDP/GTP exchange factor homolog AEX-3 has a dual function in synaptic transmission. EMBO J 19:4806-4816

64. Bezakova G, Ruegg MA (2003) New insights into the roles of agrin. Nat Rev Mol Cell Biol 4:295-308

65. Madhavan R, Zhao XT, Chan F, Wu Z, Peng HB (2003) The involvement of calcineurin in acetylcholine receptor redistribution in muscle. Mol Cell Neurosci 23:587-599

66. Campagna JA, Ruegg MA, Bixby JL (1997) Evidence that agrin directly influences presynaptic differentiation at neuromuscular junctions in vitro. Eur J Neurosci 9:22692283

67. Deverson EV, Gow IR, Coadwell WJ, Monaco JJ, Butcher GW, Howard JC (1990) MHC class II region encoding proteins related to the multidrug resistance family of transmembrane transporters. Nature 348:738-741

68. Lankat-Buttgereit B, Tampe R (2002) The transporter associated with antigen processing: function and implications in human diseases. Physiol Rev 82:187-204

69. Grewal RP, Yoshida T, Finch CE, Morgan TE (1997) Scavenger receptor mRNAs in rat brain microglia are induced by kainic acid lesioning and by cytokines. Neuroreport 8:1077-1081

70. Solari R, Smithers N, Kennard N, Ray K, Grenfell S (1994) Receptor mediated endocytosis and intracellular fate of interleukin 1. Biochem Pharmacol 47:93-101

71. Grenfell S, Smithers N, Witham S, Shaw A, Graber P, Solari R (1991) Analysis of mutations in the putative nuclear localization sequence of interleukin-1 beta. Biochem J 280:111-116

72. Grenfell S, Smithers N, Miller K, Solari R (1989) Receptor-mediated endocytosis and nuclear transport of human interleukin 1 alpha. Biochem J 264:813-822

73. Fischer DG, Novick D, Orchansky P, Rubinstein M (1988) Two molecular forms of the human interferon-gamma receptor. Ligand binding, internalization, and down-regulation. J Biol Chem 263:2632-2637

74. Paolucci C, Rovere P, De Nadai C, Manfredi AA, Clementi E (2000) Nitric oxide inhibits the tumor necrosis factor alpha-regulated endocytosis of human dendritic cells in a cyclic GMP-dependent way. J Biol Chem 275:1963819644

75. Bajzer Z, Vuk-Pavlovic S (1992) Rate transition and regulatory coupling in endocytosis of interferon-alpha and tumor necrosis factor-alpha in human epithelial tumor cells. J Cell Biochem 48:203-214 